\title{
Evaluation of Groundwater Quality and Its Suitability for Agriculture Use in Minufiya Governorate, Egypt
}

\author{
Manal F. Tantawy", W.M. Nada ${ }^{* *}$ and E.A. Abou Hussien ${ }^{* *}$ \\ *Soils, Water and Environment Institute Research, Agricultural \\ Research Center and ${ }^{* *}$ Department of Soil Science, Faculty of \\ Agriculture, Minufiya University, Minufiya, Egypt.
}

\begin{abstract}
THIS study was conducted to evaluate factors regulating groundwater quality as applied mainly for agricultural use. For these purposes, fourteen groundwater samples have been collected from different locations of Minufiya Governorate, Egypt. Minufiya governorate is located in the Nile Delta, $80 \mathrm{~km}$ north of Cairo, and its groundwater resources are developed for water supply and irrigation purposes. The groundwater samples were analyzed for various water quality parameters such as $\mathrm{pH}$, electric conductivity, soluble cations $\left(\mathrm{Na}^{+}, \mathrm{K}^{+}, \mathrm{Ca}^{+2}\right.$ and $\left.\mathrm{Mg}^{+2}\right)$, soluble anions $\left(\mathrm{Cl}^{-}, \mathrm{HCO}_{3}^{-}, \mathrm{CO}_{3}^{-2}\right.$ and $\left.\mathrm{SO}_{4}^{-2}\right)$, macronutrients $\left(\mathrm{NO}_{3}, \mathrm{NH}_{4}\right.$, total $\mathrm{P}$ and total $\left.\mathrm{K}\right)$, and micronutrients $(\mathrm{Fe}, \mathrm{Mn}, \mathrm{Zn}$ and $\mathrm{Cu})$. Chemical index like sodium percent $(\% \mathrm{Na})$, sodium adsorption ratio (SAR), residual sodium carbonated (RSC) and Kelley's ratio (KR) were calculated.
\end{abstract}

Based on the analytical results, the abundance major ions are as follows: $\mathrm{HCO}_{3}^{-}>\mathrm{Cl}^{-}>\mathrm{SO}_{4}^{-2}>\mathrm{CO}_{3}^{-2}$ and $\mathrm{Na}^{+}>\mathrm{Mg}^{+2}>\mathrm{Ca}^{+2}>\mathrm{K}^{+}$. Also, the examined samples for its content of macro and micro nutrients can be arranged as $\mathrm{K}>\mathrm{NO}_{3}-\mathrm{N}>\mathrm{NH}_{4}-\mathrm{N}>\mathrm{P}$ and $\mathrm{Fe}>\mathrm{Cu}$ or $\mathrm{Mn}>\mathrm{Zn}$, respectively. The studied water samples have $\mathrm{pH}$ values ranged between 6.88 and 7.89. The analytical results indicated that, $14.28 \%, 57.15 \%, 64.29 \%, 92.86 \%$ of ground water samples classified as good order based on EC, RSC, \% $\mathrm{Na}$ and KR parameters, respectively. On the other hand, $100 \%$ of groundwater sample is excellent for irrigation purposes based on SAR, while $50 \%$ of samples are marginally for irrigation dependable on its nitrate content. The dominant hydrochemical facies of groundwater is $\mathrm{Ca}-\mathrm{Mg}-\mathrm{HCO}_{3}$ and $\mathrm{Na}-\mathrm{Cl}-\mathrm{SO}_{4}$ type. Assessment of water samples from various methods indicated that groundwater in the study area is chemically suitable for agricultural uses without any harmful effect on soil or plant.

Keywords: Groundwater, Chemical characters, Irrigation water, Evaluation, Classification.

Water is essential to the existence of human and all living things. Groundwater occurs almost everywhere beneath the earth surface not only in a single widespread aquifer, but also in thousands of local aquifer systems. Man's activities such as food production and nutrition are dependent on water availability in adequate quantities and good quality (Howari et al., 2005). Water is the most common and widespread chemical compound in nature which is a 
major constituent of all living creatures. Groundwater which occurs beneath the earth surface is considered free from contamination, hence usable but anthropogenic as well as natural factors are affecting the quality as well as quantity of this valuable resource (Jain et al., 2009). It has been estimated that once pollution enters the subsurface environment, it may remain concealed for many years, becoming dispersed over wide areas of groundwater aquifer and rendering groundwater supplies unsuitable for consumption and other uses (Nagarajan et al., 2010).

Quality of water is assuming great importance with the rising pressure on industries and agriculture and rise in standard of living. The adequate amount of water is very essential for proper growth of plants but the quality of water used for irrigation purpose should also be well within the permissible limit otherwise it could adversely affect the plant growth (Deshpande and Aher, 2012). The water used for irrigation is an important factor in productivity of crop, its yield and quality of irrigated crops. The quality of irrigation water depends primarily on the presence of dissolved salts and their concentrations. Water chemistry differs depending on the source of water, the degree to which it has been evaporated, the types of rock and mineral it has encountered, and the time it has been in contact with reactive minerals (Arshid et al., 2011). Sodium absorption ratio (SAR) and residual sodium carbonate (RSC) are the most important quality criteria, which influence the water quality and its suitability for irrigation (USSL, 1954). In Egypt, groundwater is considered the third water resource for irrigation after the river Nile and drains. Thus it is considered an important resource to irrigate some agricultural areas in the Delta region, and some cultivated lands not accessible to Nile water (Fahim et al., 1995).

The objective of the present work is (1) to understand the sources dissolved ions, and (2) to assess the chemical quality of the groundwater through chemical analysis and (3) to investigate the concentration of the total dissolved constituents present in the ground water with respects to the standards of safe potable water. Moreover, groundwater in the study area is utilized for agricultural purposes hence hydro geochemistry is discussed in order to understand water rock interaction process.

Study area: Minufiya Governorate is located in the Nile Delta, Egypt, which lies between $30^{\circ} 10^{\prime} 14^{\prime \prime}$ to $30^{\circ} 44^{\prime} 6^{\prime \prime}$ North latitudes and $30^{\circ} 49^{\prime} 31^{\prime \prime}$ to $31^{\circ} 15^{\prime}$ 36" East longitudes. Minufiya Governorate occupies $2499 \mathrm{~km}^{2}$ with an average elevation about $12 \mathrm{~m}$ a. s. 1. (Fig. 1). The cultivated area covers approximately 331,000 feddans. The most important economic activity in the area is agriculture. Minufiya region comprise of alluvial soils which formed from the suspended solid matter of the Nile, that were deposited every year during the flood season. The suspended matter of the Nile is formed from the disintegration of the eruptive and metamorphic rocks of the Ethiopian plateau through physical, chemical and biological weathering factors. Delta alluvial soils are classified according to soil taxonomy as order Vertisols.

Egypt. J. Soil Sci. 55, No. 1 (2015) 


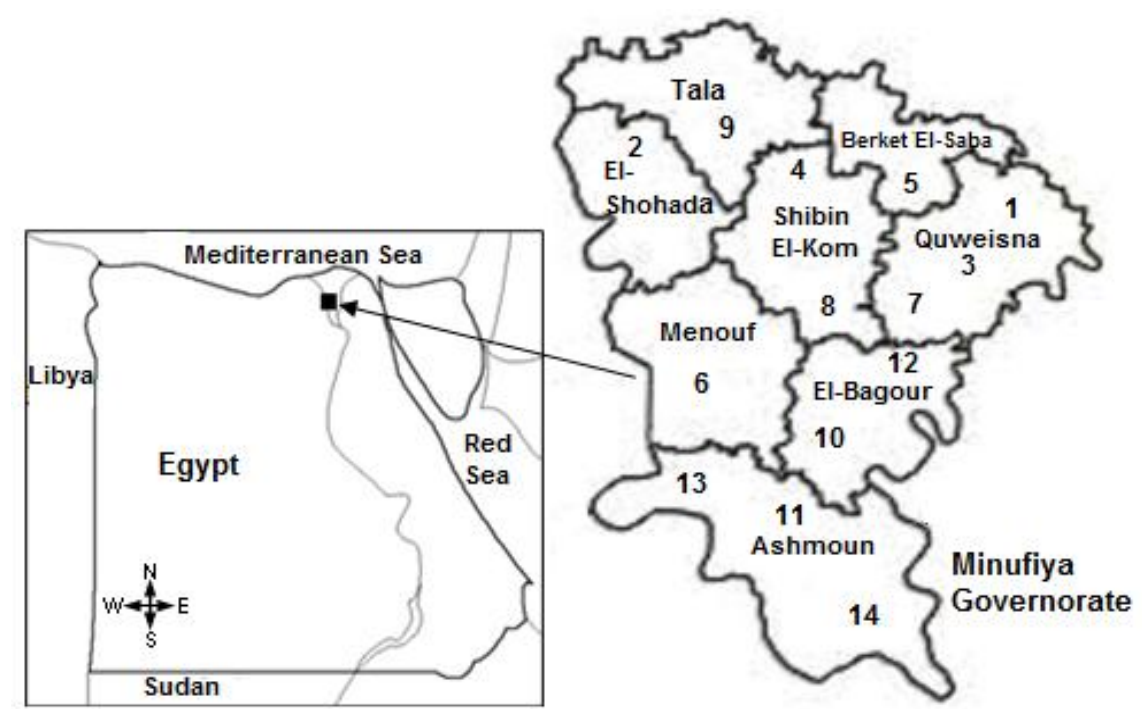

Fig. 1. Study area and groundwater sampling location.

Climate: The climate of Minufiya Governorate belongs to the arid Mediterranean type. It is characterized by a hot dry summer, and a general dryness throughout the year except during the winter season. The average annual rainfall in Minufiya Governorate is $40.5 \mathrm{~mm}$, with the highest value $(11 \mathrm{~mm})$ recorded in January. The rainfall is largely varied from year to year. The studied area falls in drought prone area hence it is characterized by the erratic behavior of the rainfall. The average of maximum temperature recorded in summer season was $32.1{ }^{\circ} \mathrm{C}$, while the average of minimum temperature recorded in winter was $18.2{ }^{\circ} \mathrm{C}$. The relative humidity of the studied area recorded an average of 55 and 54\% during winter and summer seasons, respectively. The maximum evaporation rate occurs in summer reaching $6.5 \mathrm{~mm} /$ day, with the lowest (about $4.1 \mathrm{~mm} /$ day) evaporation rate recorded in the coldest months of December and January. The average wind velocity ranged between 3.4 and $7.6 \mathrm{~m} / \mathrm{s}$, with the highest and lowest values observed in March and November, respectively.

\section{Material and Methods}

Fourteen groundwater samples from dug wells covering entire Minufiya Governorate were collected randomly during October 2012 (Fig. 1). After thirty minutes from water pumping, samples of groundwater were taken at each location separately. Samples were drawn with a precleaned plastic polyethylene bottles. Prior to sampling, all the sampling containers were washed and rinsed thoroughly with the groundwater. Water quality parameters such as $\mathrm{pH}$ and electrical conductivity (EC) were analyzed immediately (APHA, 1995). The bottles were sealed, sent to the laboratory and stored properly at $4{ }^{\circ} \mathrm{C}$ before 
analysis for other parameters. Groundwater samples were analyzed for its content of soluble ions, i.e. the cations, calcium $\left(\mathrm{Ca}^{+2}\right)$, magnesium $\left(\mathrm{Mg}^{+2}\right)$, sodium $\left(\mathrm{Na}^{+}\right)$, potassium $\left(\mathrm{K}^{+}\right)$, and the anions, chloride $\left(\mathrm{Cl}^{-}\right)$, bicarbonate $\left(\mathrm{HCO}_{3}{ }^{-}\right)$, carbonate $\left(\mathrm{CO}_{3}^{-2}\right)$ and sulfate $\left(\mathrm{SO}_{4}{ }^{-2}\right) \cdot \mathrm{Ca}^{+2}$ and $\mathrm{Mg}^{+2}$ content was determined by EDTA titration method. $\mathrm{Na}^{+}$and $\mathrm{K}^{+}$content was determined by using a flame photometer. $\mathrm{Cl}^{-}$concentration was measured by silver nitrate titration. $\mathrm{HCO}_{3}{ }^{-}$and $\mathrm{CO}_{3}{ }^{-2}$ contents were measured by acid-base titration. $\mathrm{SO}_{4}{ }^{-2}$ contents were estimated by turbid metric method using turbidity meter. The studied water samples were digested by $\mathrm{HNO}_{3}$ for measuring some selected macro and micro nutrients (Cottenie et al., 1982). $\mathrm{NO}_{3}-\mathrm{N}$ and $\mathrm{NH}_{4}-\mathrm{N}$ in groundwater samples were measured according to the methods described by Page et al. (1982). Phosphorus (P) was measured spectrophotometrically as presented by Cottenie et al. (1982). Total potassium (K) was determined photometrically, using flame photometer according to Page et al. (1982). Also, total iron (Fe), manganese $(\mathrm{Mn})$, zinc $(\mathrm{Zn})$ and copper $(\mathrm{Cu})$ were determined by atomic absorption spectrophotometer (Cottenie et al., 1982).

Groundwater quality was evaluated based on its calculated values of some chemical indexes like sodium adsorption ratio (SAR) and EC (USSL, 1954). Residual sodium carbonate (RSC), sodium percent (\%Na) and Kelly's ratio (KR) were calculated as described by Eaton (1950), Wilcox (1955) and Kelly (1940), respectively. Hydrochemical facies of the studied area was determined as demonstrated by Piper (1953). Also, the studied groundwater samples were classified according to its EC, SAR and \%Na values (USSL, 1954 and Wilcox, 1955).

\section{Results and Discussion}

\section{Groundwater chemistry}

The chemical composition of groundwater results from the geochemical processes occurring as water reacts with the geologic materials which it flows (Appelo and Postma, 2005). The water analyses included pH, EC, all major anions, cations and macro and micro nutrients of the studied samples have been described as follows.

\section{Water $\mathrm{pH}$ and salinity}

$\mathrm{pH}$ is one of the important factors of groundwater. In the study area $\mathrm{pH}$ varies from 6.88 to 7.89 (Table 1). This indicates the groundwater is neutral or slightly alkaline. The lowest $\mathrm{pH}$ value (6.88) was noticed in sample No. 10 and the highest $\mathrm{pH}$ value (7.89) appeared in sample No. 9. Except the groundwater number 10, all samples have an alkaline $\mathrm{pH}(>7.0)$. The found $\mathrm{pH}$ values for the studied groundwater lie in a safe range of $\mathrm{pH}(6.5-8.4)$. The $\mathrm{pH}$ of groundwater typically ranges from about 6.5 to 8.5 , depending on the type of soil and rock that has reacted with the groundwater (Sutharsiny et al., 2012). So, the examined groundwater is suitable for irrigation without danger of $\mathrm{pH}$ on either soil or plant (Ayers and Westcot, 1985). Electrical conductivity (EC) is an indication of the concentration of total dissolved salts and major ions in a given water body. Groundwater EC $\left(\mathrm{dSm}^{-1}\right)$

Egypt. J. Soil Sci. 55, No. 1 (2015) 
values of the study area ranged between 0.65 and $1.62 \mathrm{dSm}^{-1}$, with a minimum value being observed in sample No. 3 and maximum EC value was noticed in sample No. 10 (Table 1). The existing data suggest that, salinity of groundwater may be affected by the dissolution of salts from soil and aquifer material, and from the greatly increased infiltration from irrigated land leaching out the salts present in soil (Ayers and Westcot, 1985 and Deshpande \& Aher, 2012).

\section{Soluble cation}

The analytical results of groundwater content (meq/l) of soluble cations, i.e. $\mathrm{Na}^{+}, \mathrm{K}^{+}, \mathrm{Ca}^{+2}$ and $\mathrm{Mg}^{+2}$ are presented in Table 1 . Generally, groundwater samples in the study area appeared with the predominant cation of $\mathrm{Na}^{+}$followed by $\mathrm{Mg}^{+2}$, $\mathrm{Ca}^{+2}$ and $\mathrm{K}^{+}$. Except samples No. 3 and 12 the dominant cation was $\mathrm{Mg}^{+2}$ followed by $\mathrm{Ca}^{+2}$ and/or $\mathrm{Na}^{+}$. In all samples $\mathrm{K}^{+}$came late in the order. Water concentration of $\mathrm{Ca}^{+2}$ and $\mathrm{Mg}^{+2}$ ranged from 1.9 to $4.9 \mathrm{meq} / \mathrm{l}$ and 1.70 to $5.92 \mathrm{meq} / \mathrm{l}$, respectively. Sodium content ranged between 2.31 and $7.59 \mathrm{meq} / \mathrm{l}$, while potassium content ranged from 0.10 to $0.41 \mathrm{meq} / \mathrm{l}$. Superiority of sodium may be due to sodium compounds serve many different industrial purposes, and may also end up in water from industries and fertilizers (Ayers and Westcot, 1985).

TABLE 1. Groundwater pH, EC $\left(\mathrm{dSm}^{-1}\right)$ and their content (meq/l) of soluble ions.

\begin{tabular}{|c|c|c|c|c|c|c|c|c|c|c|}
\hline \multirow{3}{*}{$\begin{array}{c}\text { Sample } \\
\text { No. }\end{array}$} & \multirow{3}{*}{ pH } & \multirow{3}{*}{$\begin{array}{c}\mathrm{EC} \\
\left(\mathrm{dSm}^{-1}\right)\end{array}$} & \multicolumn{8}{|c|}{ Soluble ions (meq/l) } \\
\hline & & & \multicolumn{4}{|c|}{ Soluble cations } & \multicolumn{4}{|c|}{ Soluble anions } \\
\hline & & & $\mathrm{Na}^{+}$ & $\mathbf{K}^{+}$ & $\mathrm{Ca}^{+2}$ & $\mathrm{Mg}^{+2}$ & $\mathrm{HCO}_{3}^{-}$ & $\mathrm{CO}_{3}^{-2}$ & $\mathrm{Cl}^{-}$ & $\mathrm{SO}_{4}^{-2}$ \\
\hline 1 & 7.52 & 0.80 & 3.50 & 0.25 & 1.7 & 2.60 & 6.0 & 0.0 & 1.4 & 0.65 \\
\hline 2 & 7.80 & 0.74 & 2.88 & 0.31 & 2.1 & 2.30 & 6.0 & 0.0 & 1.3 & 0.29 \\
\hline 3 & 7.47 & 0.65 & 2.31 & 0.10 & 1.7 & 2.50 & 5.0 & 0.0 & 1.2 & 0.41 \\
\hline 4 & 7.19 & 0.89 & 3.91 & 0.41 & 2.2 & 2.52 & 5.9 & 0.0 & 2.0 & 1.12 \\
\hline 5 & 7.02 & 1.49 & 7.59 & 0.21 & 2.9 & 4.01 & 6.4 & 0.0 & 3.9 & 4.40 \\
\hline 6 & 7.51 & 0.82 & 4.10 & 0.10 & 1.9 & 2.30 & 4.2 & 0.0 & 2.8 & 1.40 \\
\hline 7 & 7.49 & 1.51 & 4.91 & 0.11 & 4.2 & 5.92 & 11.5 & 0.0 & 2.9 & 0.74 \\
\hline 8 & 7.65 & 0.89 & 4.12 & 0.24 & 2.0 & 2.68 & 6.5 & 0.0 & 2.3 & 0.24 \\
\hline 9 & 7.89 & 1.23 & 4.79 & 0.19 & 3.5 & 4.30 & 7.8 & 0.0 & 2.8 & 2.18 \\
\hline 10 & 6.88 & 1.62 & 5.95 & 0.34 & 4.3 & 5.90 & 8.9 & 0.0 & 3.7 & 3.89 \\
\hline 11 & 7.39 & 1.10 & 4.11 & 0.25 & 2.9 & 3.80 & 7.5 & 0.0 & 2.4 & 1.16 \\
\hline 12 & 7.01 & 1.29 & 3.44 & 0.18 & 4.0 & 4.90 & 10.0 & 0.0 & 1.8 & 0.72 \\
\hline 13 & 7.71 & 0.92 & 3.88 & 0.11 & 2.5 & 3.30 & 7.1 & 0.0 & 1.9 & 0.59 \\
\hline 14 & 7.69 & 0.95 & 3.48 & 0.21 & 2.3 & 4.00 & 8.0 & 0.0 & 1.7 & 0.29 \\
\hline Max. & 7.89 & 1.62 & 7.59 & 0.41 & 4.90 & 5.92 & 11.5 & 0.0 & 3.90 & 4.40 \\
\hline Min. & 6.88 & 0.65 & 2.31 & 0.10 & 1.90 & 1.70 & 4.2 & 0.0 & 1.20 & 0.24 \\
\hline Average & 7.44 & 1.06 & 4.21 & 0.22 & 2.91 & 3.46 & 7.2 & 0.0 & 2.29 & 1.29 \\
\hline
\end{tabular}


Moreover, sodium is a more common by product in groundwater as a result of the breakdown of clay minerals (Deshpande and Aher, 2012). Exceeding $\mathrm{Mg}^{+2}$ could be related to large number of minerals contain magnesium; magnesium is washed from rocks and subsequently ends up in water. It also ends up in the environment from fertilizer application and from cattle feed. On the contrary, low concentration of $\mathrm{K}$ is due to the fact that potassium minerals offer resistance to weathering and dissolution (Deshpande and Aher, 2012). All water samples in the study area recorded safe concentrations of soluble cations for both soil and plant (Ayers and Westcot, 1985).

\section{Soluble anion}

Water samples have a moderate content (meq/l) of soluble anions, i.e. $\mathrm{HCO}_{3}{ }^{-}$, $\mathrm{Cl}^{-}$, and $\mathrm{SO}_{4}^{-2}$ (Table 1). The predominant soluble anions of all water samples were $\mathrm{HCO}_{3}{ }^{-}$followed by $\mathrm{Cl}^{-}$, except the samples No. 5 and No. 10 which $\mathrm{HCO}_{3}{ }^{-}$ followed by $\mathrm{SO}_{4}{ }^{-2}$. The bicarbonate content in the sampling sites ranged from 4.2 meq/l in the sample No. 6 to $11.5 \mathrm{meq} / \mathrm{l}$ in the sample No. 7. Chloride contents were found to be varying from $1.2 \mathrm{meq} / \mathrm{l}$ (sample No. 3) to $3.9 \mathrm{meq} / \mathrm{l}$ (sample No.5). The sulphate content ranged between 0.24 and $4.40 \mathrm{meq} / \mathrm{l}$, with the lowest level being recorded in sample No. 8 and the highest concentration was noticed in sample No. 5. Water samples are free from any concentration of soluble carbonate, that all samples have had zero meq/l of $\mathrm{CO}_{3}{ }^{-2}$ value (Table 1). Based on cations concentration, all samples were within the maximum permissible limit for irrigation purposes according to Ayers and Westcot (1985).

\section{Groundwater content of macro and micro nutrients}

The analytical results for macro and micro nutrients of the groundwater samples collected from the study area are given in Table 2 . The data reveals that, water samples content $(\mathrm{mg} / \mathrm{l})$ of $\mathrm{NO}_{3}-\mathrm{N}$ was higher than that of $\mathrm{NH}_{4}-\mathrm{N}$. This result was attributed to that the high amounts of $\mathrm{NO}_{3}-\mathrm{N}$ may be leached down with irrigation water compared with that of $\mathrm{NH}_{4}-\mathrm{N}$. Sample No. 6 achieved the highest content of both ammonium and nitrate. The groundwater samples content $(\mathrm{mg} / \mathrm{l})$ of $\mathrm{NH}_{4}-\mathrm{N}$ ranged from 2.06 in the sample No. 2 to 4.88 in the sample No. 6. The nitrate content ranged from $3.5 \mathrm{mg} / \mathrm{l}$ in sample No. 14 to $9.8 \mathrm{mg} / \mathrm{l}$ in sample No. 6. Groundwater samples are characterized by low concentration of total $\mathrm{P}$ and ranged from $0.03 \mathrm{mg} / \mathrm{l}$ in the sample No. 5 to $0.14 \mathrm{mg} / 1$ in the sample No. 6. The found level of $\mathrm{P}$ in the examined water samples was safe and that means these waters are considered suitable for irrigation purposes (Ayers and Westcot, 1985). The total potassium contents in the sampling sites ranged from 4.29 to $15.90 \mathrm{mg} / \mathrm{l}$, with a minimum content being observed in sample No. 13 and maximum $\mathrm{K}$ content noticed in sample No. 4 (Table 2). Exceeding $\mathrm{K}$ compared with $\mathrm{P}$ and $\mathrm{N}$ in the examined water samples may be due to the type and quantities of the applied fertilizers in the study area (Appelo \& Postma, 2005 and Deshpande \& Aher, 2012). In groundwater systems, $\mathrm{NO}_{3}$ supplied either by infiltrating water or produced through nitrification, also can be removed by denitrification under anoxic conditions. Organic matter degradation is often the major source of both groundwater $\mathrm{NH}_{4}$ and $\mathrm{PO}_{4}$. Under oxic conditions, $\mathrm{NH}_{4}$ is effectively removed through nitrification while phosphorus $(\mathrm{P})$ is attenuated Egypt. J. Soil Sci. 55, No. 1 (2015) 
through sorption onto iron and aluminum oxides (Hem, 1985 and Claudette et al., 2008).

TABLE 2. Groundwater samples content (mg/l) of some macro and micronutrients.

\begin{tabular}{|l|c|c|c|c|c|c|c|c|}
\hline \multirow{2}{*}{$\begin{array}{c}\text { Sample } \\
\text { No. }\end{array}$} & \multicolumn{4}{|c|}{ Macronutrients (mg/I) } & \multicolumn{5}{c|}{ Micronutrients (mg/l) } \\
\cline { 2 - 9 } & $\mathbf{N H}_{\mathbf{4}-\mathbf{N}}$ & $\mathbf{N O}_{\mathbf{3}} \mathbf{- N}$ & $\mathbf{P}$ & $\mathbf{K}$ & $\mathbf{F e}$ & $\mathbf{M n}$ & $\mathbf{Z n}$ & $\mathbf{C u}$ \\
\hline 1 & 4.03 & 4.91 & 0.07 & 9.75 & 0.41 & 0.06 & 0.03 & 0.08 \\
\hline 2 & 2.06 & 4.18 & 0.05 & 12.10 & 0.27 & 0.08 & 0.02 & 0.15 \\
\hline 3 & 4.60 & 8.60 & 0.08 & 4.90 & 0.16 & 0.18 & 0.06 & 0.09 \\
\hline 4 & 4.10 & 5.60 & 0.08 & 15.90 & 0.68 & 0.10 & 0.07 & 0.19 \\
\hline 6 & 2.30 & 9.05 & 0.03 & 13.19 & 0.35 & 0.20 & 0.08 & 0.16 \\
\hline 7 & 4.88 & 9.80 & 0.14 & 6.90 & 0.61 & 0.41 & 0.05 & 0.18 \\
\hline 8 & 4.20 & 8.37 & 0.12 & 9.29 & 0.21 & 0.02 & 0.04 & 0.11 \\
\hline 9 & 4.8 & 6.02 & 0.09 & 9.36 & 0.74 & 0.42 & 0.12 & 0.21 \\
\hline 10 & 4.02 & 7.25 & 0.11 & 7.41 & 0.55 & 0.01 & 0.05 & 0.14 \\
\hline 11 & 2.08 & 4.05 & 0.10 & 13.20 & 0.38 & 0.32 & 0.07 & 0.21 \\
\hline 12 & 2.57 & 4.81 & 0.05 & 9.75 & 0.42 & 0.01 & 0.06 & 0.25 \\
\hline 13 & 3.20 & 4.73 & 0.13 & 7.02 & 0.45 & 0.28 & 0.04 & 0.17 \\
\hline 14 & 3.66 & 4.50 & 0.08 & 4.29 & 0.35 & 0.11 & 0.03 & 0.23 \\
\hline Max. & 3.06 & 3.50 & 0.08 & 8.19 & 0.39 & 0.11 & 0.06 & 0.13 \\
\hline Min. & 2.06 & 3.50 & 0.03 & 4.29 & 0.16 & 0.01 & 0.02 & 0.08 \\
\hline Average & 3.54 & 6.10 & 0.09 & 9.38 & 0.43 & 0.17 & 0.06 & 0.16 \\
\hline
\end{tabular}

Groundwater content of the examined total micronutrients in the study sites are recorded in Table 2. Iron was the most abundant micronutrient followed by $\mathrm{Mn}$ and/or $\mathrm{Cu}$, while $\mathrm{Zn}$ takes the lowest value. Iron concentration varied from 0.16 to $0.74 \mathrm{mg} / \mathrm{l}$ with an average of $0.43 \mathrm{mg} / \mathrm{l}$. High values of Fe compared with the others may be attributed to the weathering of marcasite and iron oxide coating in sediments which might have contributed this ion (Anandhan, 2005). Manganese was found to be in the range of 0.01 to $0.42 \mathrm{mg} / \mathrm{l}$, with a minimum level noticed in sample No. 11 and maximum value in sample No. 8 (Table 2). Zinc contents were found to be varying from 0.02 to $0.12 \mathrm{mg} / \mathrm{l}$, the lowest level being recorded in sample No. 2 and the highest Zn concentration has been observed in sample No. 8 . Copper contents in the water samples varied from 0.08 to $0.25 \mathrm{mg} / \mathrm{l}$, which accompanied sample No. 1 and sample No. 11, respectively. Generally, interpretation of macro and micro nutrients data (Table 2) shows that, all water samples are within the acceptable limit for irrigation purposes according to Ayers and Westcot (1985).

\section{Groundwater quality parameters}


Hydrochemical facies (Piper Diagram)

To know the hydrochemical regime of the study area, the analytical values obtained from the water samples are plotted on Piper (1953) trilinear diagram (Fig. $2 \& 3$ ). This diagram consists of two lower triangles that show the percentage distribution, on the milliequivalent basis, of the major cations $\left(\mathrm{Mg}^{+2}\right.$, $\mathrm{Ca}^{+2}$ and $\mathrm{Na}^{+}$plus $\left.\mathrm{K}^{+}\right)$and the major anions $\left(\mathrm{Cl}^{-}, \mathrm{SO}_{4}{ }^{-2}\right.$ and $\mathrm{CO}_{3}^{-2}$ plus $\left.\mathrm{HCO}_{3}{ }^{-}\right)$ and a diamond shaped part above that summarizes the dominant cation and anion to indicate the final water type. This classification system shows the anion and cation facies in terms of major-ion percentages. Hydrochemical facies are distinct zones that possess cation and anion concentration categories and this concept helps to understand and identify the water composition in different classes. The water types are designated according to the area in which they occur on the diagram segments (Fig. $2 \& 3$ ).

Chemical data of representative samples from the study area are presented by plotting them on a Piper diagram (Fig. 3). The cation distribution indicates that the samples range in composition form predominantly mixed cations to sodium/potassium type. In the anions triangle (triangle on the right), 13 samples plotted towards the $\mathrm{HCO}_{3}{ }^{-}$corner indicating bicarbonate type water, while one sample plotted toward mixed anion. The diamond diagram shows that majority of the groundwater samples fall in the field of mixed $\mathrm{Ca}^{+2}-\mathrm{Mg}^{+2}-\mathrm{HCO}_{3}^{-}$type and just one sample (7.14\% of the samples) belong to $\mathrm{Na}^{+}-\mathrm{Cl}^{-}-\mathrm{SO}_{4}{ }^{-2}$ type of water (Fig. 3). It is also observed from the piper plot that groundwater in the region is alkaline earths $\left(\mathrm{Ca}^{+2}\right.$ and $\left.\mathrm{Mg}^{+2}\right)$ significantly exceeds the alkalis $\left(\mathrm{Na}^{+}\right.$ and $\left.\mathrm{K}^{+}\right)$and the weak acids $\left(\mathrm{HCO}_{3}^{-}\right)$exceed the strong acids $\left(\mathrm{SO}_{4}^{-2}\right.$ and $\left.\mathrm{Cl}^{-}\right)$. The analytical results of hydrochemical facies are in harmony with those obtained by Aghazadeh \& Mogaddam (2010) and Vikas et al. (2012).

\section{Ammonium and nitrate}

Nitrogen in water occurs predominantly as either the anion nitrate $\left(\mathrm{NO}_{3}\right)$ under oxidizing conditions or the cation ammonium $\left(\mathrm{NH}_{4}\right)$ under reducing conditions. Ammonium is unstable in oxidizing environments such as aerated groundwater (Hem, 1985). For this reason, high concentration of $\mathrm{NH}_{4}$ in shallow groundwater is indicator of likely contamination by sewage or other forms of organic waste. Nitrate is commonly used as fertilizer; high nitrate concentrations generally indicate contamination by fertilizer or by either human or animal organic waste. The analytical data in Table 2 and its classification categories recorded in Table 4 show that, all water samples having less than $5 \mathrm{mg} / \mathrm{lof} \mathrm{NH}_{4}$ value. Thus, groundwater is suitable for irrigation without danger of ammonium on either soil or plant (Ayers and Westcot, 1985). However and based on $\mathrm{NO}_{3}$, $50 \%$ of water samples are suitable and $50 \%$ of water samples having marginally quality for irrigation (Table 4).

\section{Chloride ( $\mathrm{Cl})$}

Chloride originates from sodium chloride which gets dissolved in water from rocks and soil. It is good indicator of groundwater quality and its concentration in groundwater will increase if mixed with sewage or sea water. The minimum

Egypt. J. Soil Sci. 55, No. 1 (2015) 
and maximum contents of $\mathrm{Cl}^{-}$were 1.2 and 3.9 meq/l, respectively (Table 1). As per the classification based on all of water samples $(100 \%)$ belong to suitable group, which all samples having less than $4 \mathrm{meq} / \mathrm{l}$ of $\mathrm{Cl}^{-}$value (Table 4 ). Thus, groundwater is suitable for irrigation without danger of chloride on either soil or plant (Ayers and Westcot, 1985).
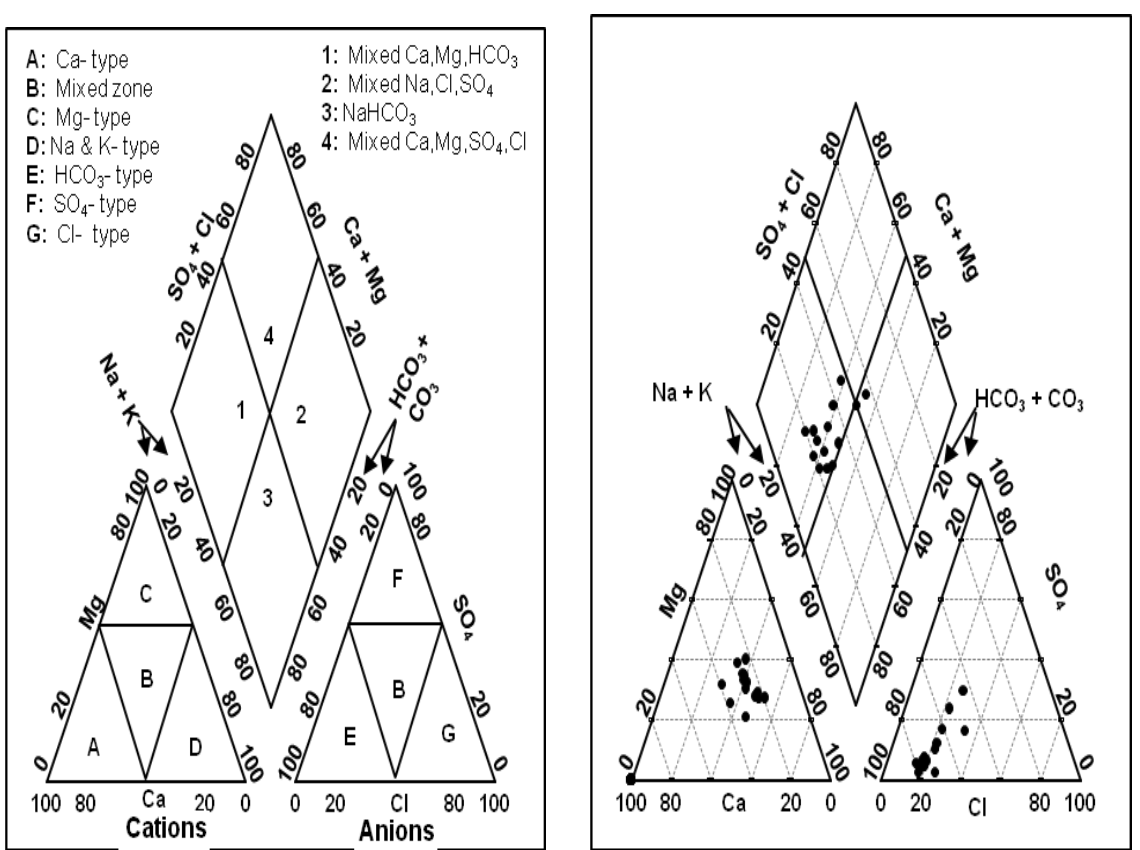

Left: Trilinear diagram showing water type, right: Piper diagram reflecting studied water type.

Fig . 2 and 3. Chemical facies of groundwater samples plotted in Piper diagram.

\section{Electrical conductivity (EC)}

The most significant water quality guideline on crop productivity is the salinity hazard as measured by electrical conductivity (EC). Classification of groundwater based on salinity hazard was done according to the recommendation of Wilcox (1955). Based on EC data presented in Table 1 and its classification groups recorded in Table 4, $14.28 \%$ of the selected wells have good quality, $85.72 \%$ have doubtful quality and no wells come under unsuitable for irrigation. Also, the presented data in Table 4 indicate two water samples can be used for irrigation without EC problem and high attention could be taken when adding the other water samples to the soil (Wilcox, 1955). The primary effect of high EC water on crop productivity is the inability of the plant to compete with ions in the soil solution for water. Higher the EC, less water is available to plants (Tatawat and Chandel, 2008).

TABLE 3. Groundwater values of SAR, \% Na, RSC and KR parameters in the studied area. 


\begin{tabular}{|l|c|c|c|c|}
\hline Sample No. & SAR & \% Na & RSC (meq/I) & KR \\
\hline 1 & 2.61 & 43.5 & 1.70 & 0.81 \\
\hline 2 & 1.60 & 37.9 & 1.60 & 0.65 \\
\hline 3 & 1.26 & 34.9 & 0.80 & 0.55 \\
\hline 4 & 2.58 & 43.3 & 1.20 & 0.83 \\
\hline 5 & 4.10 & 51.6 & -0.50 & 1.10 \\
\hline 6 & 2.34 & 48.8 & 0.00 & 0.98 \\
\hline 7 & 2.18 & 32.4 & 1.38 & 0.49 \\
\hline 8 & 2.26 & 45.6 & 1.82 & 0.88 \\
\hline 9 & 2.43 & 37.5 & 0.00 & 0.61 \\
\hline 10 & 2.63 & 36.1 & -1.30 & 0.58 \\
\hline 11 & 1.87 & 37.2 & 0.80 & 0.61 \\
\hline 12 & 1.63 & 27.5 & 1.10 & 0.39 \\
\hline 13 & 2.32 & 39.6 & 1.50 & 0.67 \\
\hline 14 & 1.96 & 34.8 & 1.70 & 0.55 \\
\hline Max. & 4.10 & 51.60 & 1.82 & 1.10 \\
\hline Min. & 1.26 & 27.50 & -1.30 & 0.39 \\
\hline Average & 2.27 & 39.34 & 0.84 & 0.69 \\
\hline
\end{tabular}

TABLE 4. Classification of groundwater on the basis of $\mathrm{NO}_{3}, \mathrm{NH}_{4}, \mathrm{Cl}, \mathrm{EC}, \mathrm{SAR}$, SSP, KR and RSC parameters.

\begin{tabular}{|c|c|c|c|c|}
\hline Parameter & Range & Water class & No. of sample & $\%$ of samples \\
\hline \multirow{3}{*}{$\begin{array}{l}\mathrm{NO}_{3}-\mathrm{N}(\mathrm{mg} / 1) \\
\text { (Ayers and Westcot, 1985) }\end{array}$} & $<5$ & Suitable & 7 & 50.0 \\
\hline & $5-30$ & Marginally & 7 & 50.0 \\
\hline & $>30$ & Unsuitable & - & - \\
\hline \multirow{3}{*}{$\begin{array}{l}\mathrm{NH}_{4}-\mathrm{N}(\mathrm{mg} / 1) \\
\text { (Ayers and Westcot, 1985) }\end{array}$} & $<5$ & Suitable & All & 100 \\
\hline & $5-30$ & Marginally & - & - \\
\hline & $>30$ & Unsuitable & - & - \\
\hline \multirow{3}{*}{$\begin{array}{l}\mathrm{Cl}^{-}(\mathrm{meq} / \mathrm{l}) \\
\text { (Ayers and Westcot, 1985) }\end{array}$} & $<4$ & Suitable & All & 100 \\
\hline & $4-10$ & Marginally & - & - \\
\hline & $>10$ & Unsuitable & - & - \\
\hline \multirow{4}{*}{$\begin{array}{l}\text { EC (micromhos/cm) } \\
\text { (USSL, 1954) }\end{array}$} & $<250$ & Excellent & - & - \\
\hline & $250-750$ & Good & 2 & 14.28 \\
\hline & $750-2250$ & Doubtful & 12 & 85.72 \\
\hline & $>2250$ & Unsuitable & - & - \\
\hline \multirow{4}{*}{$\begin{array}{l}\text { SAR } \\
\text { (USSL, 1954) }\end{array}$} & $<10$ & Excellent & All & 100 \\
\hline & $10-18$ & Good & - & - \\
\hline & $18-26$ & Doubtful & - & - \\
\hline & $>26$ & Unsuitable & - & - \\
\hline \multirow{3}{*}{$\begin{array}{l}\mathrm{RSC}(\mathrm{meq} / \mathrm{l}) \\
\text { (Eaton, 1950) }\end{array}$} & $<1.25$ & Good & 8 & 57.15 \\
\hline & $1.25-2.50$ & Doubtful & 6 & 42.85 \\
\hline & $>2.50$ & Unsuitable & - & - \\
\hline \multirow{5}{*}{$\begin{array}{l}\% \mathrm{Na} \\
\text { (Wilcox, 1955) }\end{array}$} & $<20$ & Excellent & - & - \\
\hline & $20-40$ & Good & 9 & 64.29 \\
\hline & $40-60$ & Permissible & 5 & 35.71 \\
\hline & $60-80$ & Doubtful & - & - \\
\hline & $>80$ & Unsuitable & - & - \\
\hline \multirow{2}{*}{$\begin{array}{l}\text { KR } \\
\text { (Kelley, 1940) }\end{array}$} & $<1$ & Good & 13 & 92.86 \\
\hline & $>1$ & Unsuitable & 1 & 7.14 \\
\hline
\end{tabular}

Sodium adsorption ratio (SAR)

Egypt. J. Soil Sci. 55, No. 1 (2015) 
The sodium adsorption ration (SAR) indicates the effect of relative cation concentration on sodium accumulation in the soil; thus, SAR is a more reliable method for determining this effect than sodium percentage (USSL, 1954). Sodium adsorption ration (SAR) is calculated using the following formula (1), where all ionic concentrations are expressed in meq/l.

$$
\mathrm{SAR}=\mathrm{Na} /[(\mathrm{Ca}+\mathrm{Mg}) / 2]^{1 / 2}
$$

Sodium adsorption ratio (SAR) is considered one of the important parameters used to define and determine water quality and its suitability for irrigation (USSL, 1954). The calculated values of SAR were recorded in Table 3 and its classification groups recorded in Table 4. The maximum and minimum values of SAR were 4.10 and 1.26 , respectively. As per the classification based on all of water samples (100\%) belong to excellent group, that all samples having less than 10 of SAR value. Thus, groundwater is suitable for irrigation without danger of exchangeable sodium on either soil or plant (USSL, 1954).

\section{Sodium percent $(\% \mathrm{Na})$}

Sodium concentration plays an important role in evaluating irrigational quality of groundwater. A high concentration of sodium is undesirable as sodium is adsorbed on the exchange sites causing soil aggregates to disperse, reducing its permeability (Arshid et al., 2011). The sodium in irrigation waters is also expressed as percent sodium or soluble sodium percentage $(\% \mathrm{Na})$ and it was calculated by using formula (2) proposed by Wilcox (1955), where all ionic concentrations are expressed in meq/l.

$$
\% \mathrm{Na}=[\mathrm{Na} /(\mathrm{Ca}+\mathrm{Mg}+\mathrm{K}+\mathrm{Na})] * 100
$$

The calculated results in Table 3 and its classification categories presented in Table 4 show that, the highest value (51.6) of \% Na recorded to sample number 5, while the lowest value (27.5\%) associated water sample number 12. The classification of groundwater samples with respect to percent sodium is shown in Table 4. Out of selected wells, $64.29 \%$ ( 9 samples) have good irrigation water quality and $35.71 \%$ ( 5 samples) have permissible irrigation water quality (Tables $3 \& 4$ ). When the concentration of sodium ion is high in irrigation water, $\mathrm{Na}$ + tends to be absorbed by clay particles, displacing magnesium and calcium ions. This exchange process of sodium in water for $\mathrm{Ca}^{+2}$ and $\mathrm{Mg}^{+2}$ in soil reduces the permeability and eventually results in soil with poor internal drainage (Tatawat and Chandel, 2008).

\section{Residual sodium carbonate (RSC)}

Residual sodium carbonate (RSC) has been calculated to determine the hazardous effect of carbonate and bicarbonate on the quality of water for agricultural purpose and has been determined by the equation (3) as described by Eaton (1950), where all ionic concentrations are expressed in meq/l.

$$
\mathrm{RSC}=\left(\mathrm{HCO}_{3}+\mathrm{CO}_{3}\right)-(\mathrm{Ca}+\mathrm{Mg})
$$


In water having high concentration of bicarbonate there is tendency for calcium and magnesium to precipitate as carbonates. The classification of water quality for irrigation on the basis of RSC was proposed by Eaton (1950) and is shown in Table 4 . The values of RSC range from -1.30 to $1.82 \mathrm{meq} / \mathrm{l}$ with an average value $0.84 \mathrm{meq} / \mathrm{l}$ (Table 3 ). Based on RSC values, 8 samples of study area having values less than $1.25 \mathrm{meq} / \mathrm{l}$ and were safe for irrigation while 6 samples are with range 1.25-2.5 meq/l and indicate doubtful category for irrigation purposes.

\section{Kelly's ratio (KR)}

Sodium measured against $\mathrm{Ca}^{+2}$ and $\mathrm{Mg}^{+2}$ is used to calculate Kelley's ratio (Kelly, 1940). The formula used in the estimation of Kelley's ratio is expressed in equation (4).

$$
\mathrm{KR}=\mathrm{Na}^{+} /\left(\mathrm{Ca}^{+2}+\mathrm{Mg}^{+2}\right)
$$

A Kelley's ratio (KR) of more than one indicates an excess level of sodium in waters. Hence, waters with a Kelley's ratio less than one are suitable for irrigation, while those with a ratio more than one are unsuitable for irrigation. 92.86\% Kelley's ratio (KR) values for the groundwater of study area are less than 1 and indicate good quality water for irrigation purpose while remaining $7.14 \%$ is more than 1 indicates the unsuitable water quality for irrigation (Table 4). Based on this classification, all of groundwater samples belong to the good category except one sample which falls in unsuitable category (Table 4$)$.

\section{Classification of groundwater}

The combination of EC and SAR had also been used to determine the suitability of water for irrigation. The US salinity diagram (U.S. Salinity Laboratory Staff, 1954) was used to classify the groundwater samples for irrigation (Fig. 4, left side). In US salinity diagram, EC is taken as salinity hazard and SAR as alkalinity hazard. Out of 12 ground water samples tested, $85.72 \%$ fall under C3S1, indicating high salinity and low alkali hazard. $14.28 \%$ of wells (2 samples) fall in $\mathrm{C} 2 \mathrm{~S} 1$ quality with medium salinity hazard and low sodium hazard. Moreover, the classification of groundwater samples from the study area with respect to salinity hazard (EC) and sodium percentage $(\% \mathrm{Na})$ is represented in Fig. 4, (right side) according to Wilcox (1955). The Wilcox diagram relating sodium percentage and electrical conductivity shows that, $85.72 \%$ of the groundwater samples fall in the field of good to permissible and $14.28 \%$ of the groundwater samples fall in the field of excellent to good for irrigation. Base on the US salinity and Wilcox diagrams (Fig. 4), it can conclude that the examined groundwater sources can be used to irrigate all types of soils with little danger of exchangeable sodium. Also, this water can be used on soils with considerable drainage like in the case of the study area. However, even with adequate drainage, special measures for salinity control may be required. Salt tolerant 
plants like asparagus, beet, sorghum, and cauliflower could be selected to grow in these soils (Sutharsiny et al., 2012).
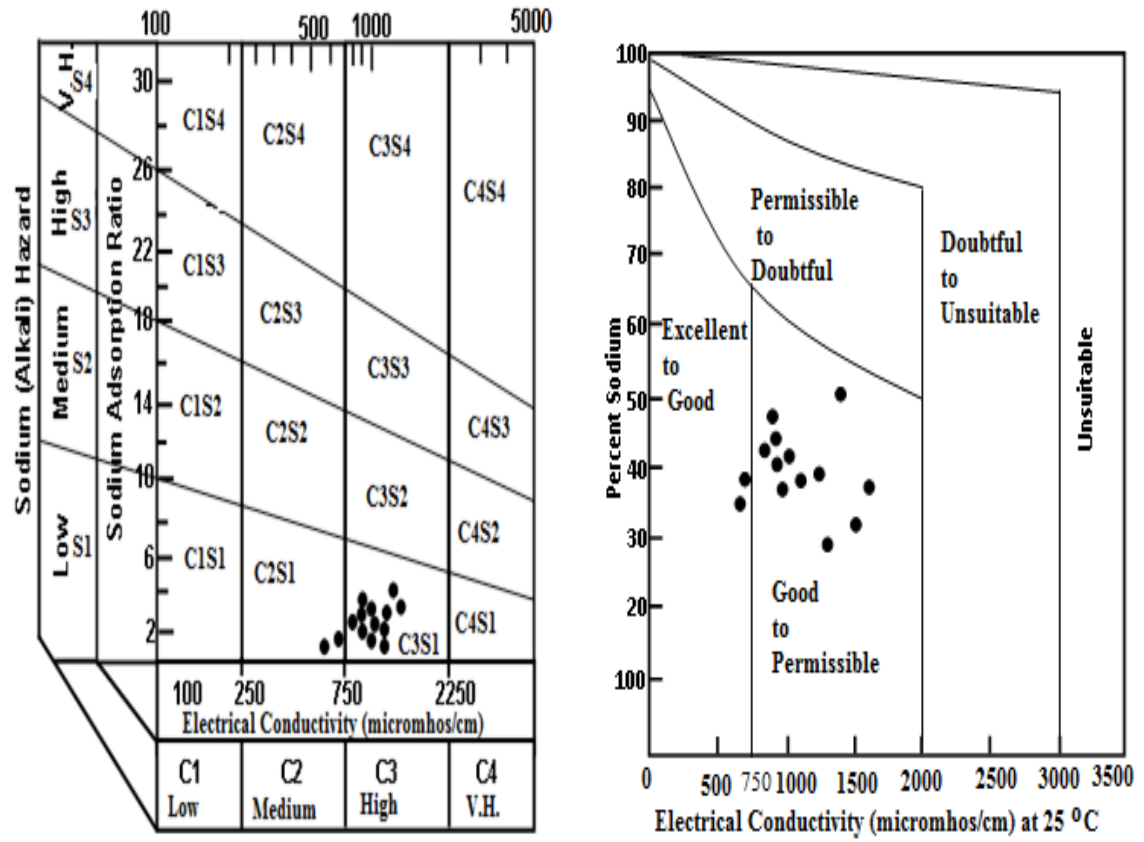

Left: after USSL (1954), right: after Wilcox (1955) .

Fig. 4. Rating of groundwater samples in relation to salinity, sodium hazard and percent sodium.

\section{Conclusion}

1. The type of water that predominates in the study area is $\mathrm{Ca}-\mathrm{Mg}-\mathrm{HCO}_{3}$ type during the year 2009, based on hydrochemical facies.

2. Though the suitability of water for irrigation is determined based on SAR, SSP, RSC, KR and salinity hazard, it is only an empirical conclusion. In addition to water quality, other factors like soil type, crop type, crop pattern, frequency and recharge (rainfall), climate, ... etc. have an important role to play in determining the suitability of water.

3. Water that is not suitable based on the above classification may be suitable in well-drained soils.

4. The suitability of water for irrigation is evaluated based on SAR, \% Na, RSC and salinity hazards. Most of the samples in Minufiya Governorate fall in the suitable range for irrigation purpose either from SAR, SSP, RSC or KR values.

5. About $86 \%$ of the samples are grouped within C3S1 classes and about $14 \%$ of the samples are located in $\mathrm{C} 2 \mathrm{~S} 1$ classes (Fig. 4). 
6. Most of the samples in Minufiya Governorate fall in the suitable range for irrigation purpose from USSL and Wilcox diagrams.

Acknowledgments : This study was supported by Faculty of Agriculture, Minufiya University. The authors gratefully acknowledge the Soil Science Department Authority for supplying the existing relevant data. We would like to thank Prof. Dr. M.S.E. Amira for his kind help during the field visits and the collection of data.

\section{References}

Aghazadeh, N. and Mogaddam, A.A. (2010) Assessment of groundwater quality and its suitability for drinking and agricultural uses in the Oshnavieh Area, northwest of Iran. Journal of Environmental Protection, 1, 30-40.

APHA (American Public Health Association) (1995) Standard Methods for Examination of Water and Waste Water. $15^{\text {th }}$ ed. American Pub. Health Asso., Washington D.C.

Anandhan, P. (2005) Hydrogeochemical studies in and around Neyveli mining region, Tamil Nadu, India. PhD Thesis, Department of Earth Sciences, Annamalai University, $189 \mathrm{p}$.

Appelo, C.A.J. and Postma, D. (2005) Geochemistry, Groundwater and Pollution. $2^{\text {nd }}$ ed., Balkema, Rotterdam, pp. 649.

Arshid, J., Aasimah T., Yousuf, A.R., Akbar, M. and Aabid, H.N. (2011) Geochemistry and irrigation quality of groundwater along River Jhelum in South Kashmir, India. Recent Research in Science and Technology, 3 (6), 57-63.

Ayers, R.S. and Westcot, D.W. (1985) Water Quality for Agriculture. FAO. Irrigation and Drainage Paper No. 29. Food and Agriculture Organization of the United Nations, Rome, pp. 1-117.

Claudette, S., Caroline, P.S., Matthew, A.C., Kagan, T. and Christof, M. (2008) Flow and nutrient dynamics in a subterranean estuary (Waquoit Bay, MA, USA): Field data and reactive transport modeling. Geochimica et Cosmochimica Acta, 72, 3398-3412.

Cottenie, A., Verloo, M., Kiekens, L., Velghe, A. and Camerlynck, R. (1982) Chemical Analysis of Plants and Soils. Lab. Anal. and Agrochem. State University Ghent, Belgium.

Deshpande, S.M. and Aher, K.R. (2012) Evaluation of groundwater quality and its suitability for drinking and agriculture use in parts of Vaijapur, District Aurangabad, MS, India. Research Journal of Chemical Sciences, 2 (1), 25-31.

Eaton, F.M. (1950) Significance of carbonate in irrigation water. Soil Science, 69 (2), 123-133.

Fahim, F.A., Mousa, S.A. and Abdel Aleem, M.K. (1995) Studies on the ground water at an agricultural area, Nile Delta, Egypt. Proc. $1^{\text {st }}$ International Conference on the Egypt. J. Soil Sci. 55, No. 1 (2015) 
Environment and Development in Africa. Vol. 1. Assiut, Egypt, Assiut University Center for Environmental Studies, 215.

Hem, J.D. (1985) Study and interpretation of the chemical characteristics of natural water. U.S. Geological Survey Water-Supply Paper 2254, $3^{\text {rd }}$ ed., 263 p.

Howari, F.M., Abu-Rukah, Y. and Shinaq, R. (2005) Hydrochemical analysis and evaluation of ground water resources of North Jordan. Water Resources, 32 (5), 555- 564.

Jain, C.K., Bandyopadhyay, A. and Bhadra, A. (2009) Assessment of ground water quality for drinking purpose, District Nainital, Uttarakhand, India. Environmental Monitoring Assessment, 166, 663-673.

Kelley, W.P. (1940) Permissible composition and concentration of irrigation waters, Proc. ASCE, 66, 607.

Nagarajan, R., Rajmohan, N., Mahendran, U. and Senthamilkumar, S. (2010) Evaluation of groundwater quality and its suitability for drinking and agriculture use in Thanjavur city, Tamil Nadu, India. Environmental Monitoring Assessment, 171, 289-308.

Page, A.L., Miller, R.H. and Keeney, D.R. (1982) Methods of Soil Analysis. Part 2. Chemical and Microbiological Properties, $2^{\text {nd }}$ ed. ASA and SSSA, Madison, Wisconsin, U.S.A.

Piper, A.M. (1953) A graphic procedure in the geochemical interpretation of water analysis, USGS groundwater note no, p.12.

Sutharsiny, A., Pathmarajah, S., Thushyanthy, M. and Meththika, V. (2012) Characterization of irrigation water quality of Chunnakam Aquifer in Jaffna Peninsula. Tropical Agricultural Research, 23 (3), 237-248.

Tatawat, R.K. and Chandel, C.P.S. (2008) Quality of groundwater of Jaipur city, Rajasthan (India) and its suitability for domestic and irrigation purpose. Applied Ecology and Environmental Research, 6 (2), 79-88.

USSL (US Salinity Laboratory) (1954) Diagnosis and Improvement of Saline and Alkali Soils. Agricultural Handbook, USDA, No. 60, pp. 160.

Vikas, T., Kamra, S.K., Kumar, S., Kumar, A. and Vishal, K. (2012) Hydro-chemical analysis and evaluation of groundwater quality for irrigation in Karnal district of Haryana state, India. International Journal of Environmental Researches, 3 (2), 756-766.

Wilcox, L.V. (1955) Classification and use of irrigation waters, Agric. Circ. 969, USDA, Washington D.C., pp. 19.

(Received 6/4/2014; accepted 30/9/2014) 


\section{تقييم جودة الماء الأرضى ومدى صلاحيته للإستخدام الزراعى فى محافظة المنوفية ـ مصرة الارضى}

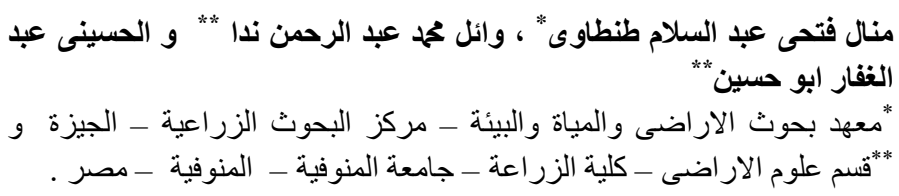

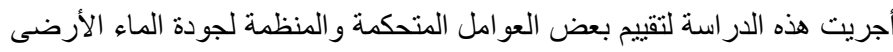

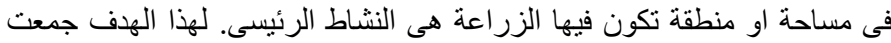

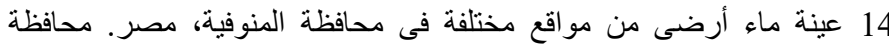

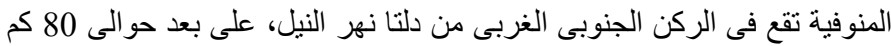

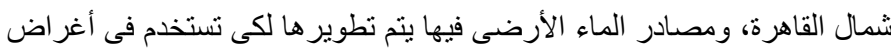

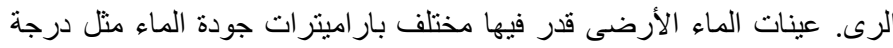

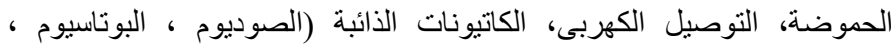

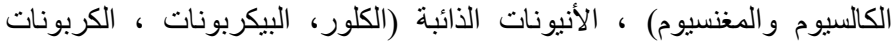

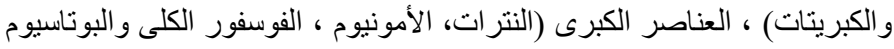

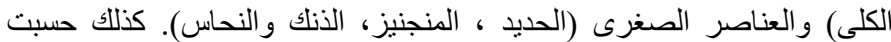

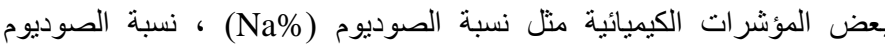

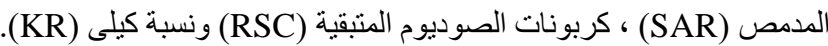

إستناداً إلى النتائج المتحصل عليها رتبت الأيونات من حيث وجودها كالنالى:

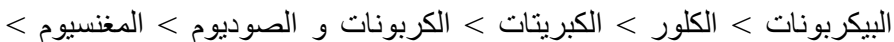

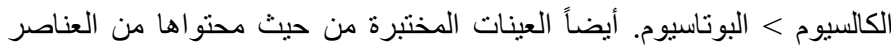

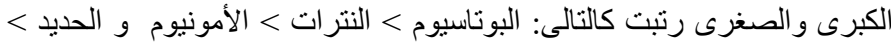

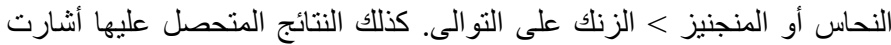

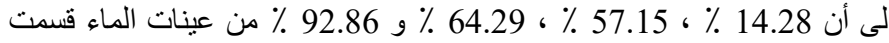

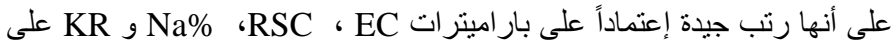

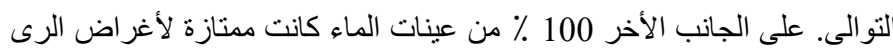

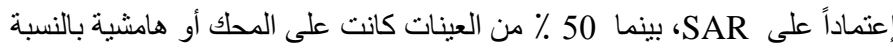

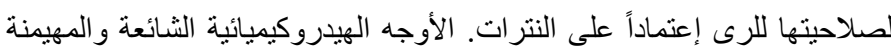

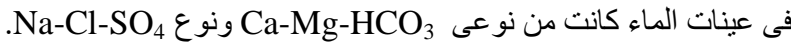
تقييم عينات الماء بمختلف الطرق أثار الى أن الماء الأرضى في المساحة

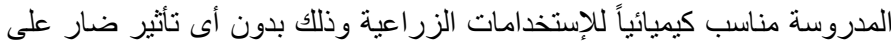

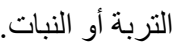

